\title{
HUBUNGAN MOTIVASI DAN KEPEMIMPINAN TERHADAP DISIPLIN KERJA GURU (Studi Di Kantor SDN Ngronggo 2 Kecamatan Kota Kediri)
}

\author{
Syahadzan Muhammad Iqbal ${ }^{1)}$, *A.A Bakar ${ }^{2)}$, Hariyanto ${ }^{3)}$ \\ 1) Program Studi Administrasi Publik Universitas Kadiri, Indonesia \\ 2) Program Studi Administrasi Publik Universitas Kadiri, Indonesia \\ 3) Program Studi Administrasi Publik Universitas Kadiri, Indonesia \\ *Email Korespondensi : aabakar@unik-kediri.ac.id
}

\begin{abstract}
Abstrak
Pendidikan merupakan salah satu variabel penentu kemajuan suatu bangsa. Pendidikan yang maju maju pula bangsanya, pendidikan yang terbelakang maka terbelakang pula bangsanya. Sementara itu guru merupakan variabel penentu maju dan mundurnya bangsa di kanca internasional. Guru merupakan barisan terdepan dalam terlibat langsung untuk proses pendidikan. Bicara maju mundurnya bangsa maka biara juga maju mundurnya pendidikan. Oleh karena itu guru harus tetap memiliki motivasi yang tinggi manakala menjalankan tugas, yaitu mengajar, membimbing, dan membina anak didik. Menyadari tugasnya yang sangat menentukan bagi generasi mendatang, maka seorang guru harus memiliki bekal yang cukup. Beberapa hal yang sangat krusial harus dimiliki seorang guru dalam menjalankan tugasnya adalah motivasi, kepemimpinan dan disiplin kerja, Permasalahannya adalah apakah apakah factor motivasi dan kepemimpinan memiliki hubungan yang signifikan dengan disiplin kerja. Pendekatan yang digunakan dalam melaksanakan penelitian ini adalah pendekatan kuantitatif, dengan analisis statistik dengan rumus Korelasi Product moment. Adapun sampel dan populasi sama yaitu 19 responden (sampel total). Variabel bebasnya adalah motivasi dan kepemimpinan adapun variabel terikatnya adalah disiplin kerja guru. Teknik pengumpulan data dengan teknik pengisian kuesioner, interview, observasi dan dokumentasi.
\end{abstract}

Kata Kunci: Motivasi; Kepemimpinan; Disiplin Kerja

\begin{abstract}
Education is one of the determinants of the progress of a nation. Education is also advanced forward by the nation, education is backward then the nation is also underdeveloped. Meanwhile the teacher is the determining variable for the progress and decline of the nation in the international arena. Teachers are at the forefront of being directly involved in the education process. Talking about the decline of the nation, the monastery also had the retreat of education. Therefore teachers must remain highly motivated when carrying out tasks, namely teaching, guiding, and fostering students. Realizing their very decisive tasks for future generations, a teacher must have enough stock. Some very crucial things that must be owned by a teacher in carrying out their duties are motivation, leadership and work discipline. The problem is whether
\end{abstract}


the motivation and leadership factors have a significant relationship with work discipline. The approach used in carrying out this research is a quantitative approach, with statistical analysis with the Product moment Correlation formula. The same sample and population are 19 respondents (total sample). The independent variable is motivation and leadership while the dependent variable is the teacher's work discipline. Data collection techniques by filling out questionnaires, interviews, observation and documentation.

Keywords: Motivation; Leadership; Work Discipline

\section{PENDAHULUAN}

Guru merupakan ujung tombak dari berbagai kebijakan pendidikan nasional dalam rangka terus meningkatkan kualitas pendidikan di Tanah Air. Maka seorang guru harus memiliki komitmen yang tinggi dalam melaksanakan tugasnya yang semakin lama semakin berat guna mencapai tujuan pendidikan nasional. Faktor kedisiplinan guru merupakan kerangka utama dalam mencapai tujuan pendidikan nasional tersebut, dan sebagai salah satu tolok ukur terhadap kualitas kerja dalam keseharian.

Disiplin kerja yang baik tercermin pada bagaimana dalam menjalankan tugas dan fungsinya sebagai guru dalam menjalankan tugasnya. Motivasi dari kepala sekolah untuk tenaga pendidik dan kependidikan sangat di perlukan guna menjalankan tugas dan fungsi agar lebih baik. Peran guru dalam menjalankan tugasnya tidak hanya sekedar bidang kegiatan pembelajaran saja, melainkan juga sebagai motivator dari para siswanya, juga guru lain. Tercapainya tujuan pendidikan membutuhkan guru yang memiliki tanggung jawab pada tugasnya, berdedikasi tinggi dan loyalitas pada pimpinan serta berdisiplin dalam bekerja. Tanpa adanya motivasi guru hanya cepat merasa jenuh karena tidak adanya unsur pendorong dan jika itu dibiarkan maka tujuan pendidikan yaitu peningkatan mutu pendidikan tidak akan berjalan dengan baik.

Kehadiran guru dalam proses pembelajaran di sekolah masih tetap memegang peranan penting yang belum tergantikan oleh apapun termasuk teknologi informasi. Dalam Peraturan Pemerintah No. 74 Tahun 2008 tentang guru, Pasal 1 menegaskan bahwa guru adalah pendidik profesional dengan tugas utama mendidik mengajar membimbing, mengarahkan, melatih, menilai, dan mengevaluasi siswa. Pada dasarnya upaya peningkatan mutu pendidikan sangat dipengaruhi oleh tingkat komitmen dan profesionalitas guru dalam melaksanakan tugasnya di sekolah. Kurangnya komitmen 
kerja guru dapat dilihat dari seberapa lama guru berada di sekolah, dan bagaimana kelengkapan pembelajaran yang dimiliki. Jadi kalau ada guru berada di sekolah kalau hanya ada jam mengajar saja, jells guru demikian tidak termasuk guru yang berdedikasi tinggi, loyal pada pimpinan dan tidak berkomitmen untuk meningkatkan kualitas pendidikan dan pembelajaraan.

Berbagai upaya telah dilakukan untuk mengoptimalkan proses belajar mengajar di kelas. Bentuk upaya pemerintah tersebut antara lain melaksanakan program penataran untuk meningkatkan kompetensi guru, pengenalan metode metode baru dalam pembelajaran, serta perbaikan dan peningkatan sarana maupun prasarana pendidikan. Namun demikian, meskipun secara eksplisit diakui bahwa pembelajaran dan sekolah merupakan faktor yang menentukan keberhasilan proses pembelajaran di dalam kelas, tetapi juga harus diakui bahwa program-program yang dilaksanakan belum menyentuh atau masih mengabaikan hal-hal yang juga cukup berpengaruh pada peningkatan kualoitas pendidikan, tidak hanya sekedar materi saja. Oleh karena itu peranan kepala sekolah sebagai pemimpin dalam pendidikan formal perlu memiliki wawasan kedepan.

Menurut Soebagio dalam Suwarno (2000:2) kepemimpinan pendidikan memerlukan perhatian yang utama, karena melalui kepemimpinan yang baik kita harapkan akan lahir tenaga-tenaga berkualitas dalam berbagai bidang sebagai pemikir, pekerja yang pada akhirnya dapat meningkatkan sumber daya manusia yang berkualitas. Motivasi pimpinan dapat di wujudkan berupa material maupun penghargaan misalnya dapat berupa kenaikan gaji istimewa, bingkisan. Bagi pegawai yang berprestasi perlu mendapatkan reward dan bagi pegawai yang ingin meningkatkan kemampuan dan pengetahuannya perlu memperoleh pelatihan atau workshop. Pertanyaannya apakah motivasi dan kepemimpinan memiliki hubungan terhadap disiplin kerja guru (Kasus di kantor SDN Ngronggo 2 Kota Kediri).

\section{TINJAUAN PUSTAKA}

Menurut (Potu, 2013) "Motivasi adalah kondisi yang berpengaruh membangkitkan mengarahkan dan memelihara perilaku yang berhubungan dengan lingkungan kerja". Sedangkan menurut (Brahmasari \& Suprayetno, 2008), "motivasi 
merupakan kondisi atau energi yang menggerakkan diri yang terarah atau tertuju untuk mencapai tujuan". Sementara itu menurut (REZA \& Dirgantara, 2010) motivasi suatu dorongan jiwa yang membuat seseorang tergerak untuk melakukan tindakan yang produktif, baik yang berorientasi kerja menghasilkan uang maupun yang tidak. Motivasi merupakan faktor penyemangat sehingga melalui motivadi tercipta semangat kerja dan kedisiplinan (Sriwidodo \& Haryanto, 2010).

Berdasarkan pendapat diatas dapat disimpulkan bahwa motivasi kerja adalah suatu hal yang timbul dalam diri untuk bersemangat melakukan suatu hal atau bisa dikatakan sebagai bom yang meledak ledak di dalam diri. Motivasi yang ada pada seseorang akan mewujudkan suatu perilaku yang diarahkan pada tujuan mencapai sasaran kepuasan. Jadi motivasi bukanlah sesuatu yang dapat diamati tetapi adalah hal-hal yang dapat disimpulkan adanya karena sesuatu perilaku yang tampak.

Secara garis besar, motivasi dapat dibedakan menjadi dua, yaitu motivasi positif dan motivasi negative. Hal tersebut sebagaimana dijelaskan oleh Ranupandojo dan (Firmansyah, 2009) "Motivasi yang muncul sebagai akibat pemberian reward, adapun motivasi yang muncul sebagai akibat adanya sangsi karena pelanggaran disebut dengan motivasi negative".

Terdapat dua konsep dalam motivasi, yaitu konsep kepuasan sebuah konsep yang menggunakan pendekatan atas faktor-faktor kebutuhan dan kepuasan individu yang menyebabkannya bertindak dan berperilaku dengan cara tertentu. Adapun yang kedua yang dikenal dengan konsep proses, yaitu konsep yang memusatkan perhatiannya pada bagaimana motivasi terjadi, dan bergerak seolah olah lingkungan disekitarnya mengikuti arus pusat yang ada dalam diri. Adapun proses motivasi adalah pikiran yang menggambarkan sesuatu yang timbul dalam pikiran dan menggerakkan tingkah laku.Selain itu proses motivasi juga timbul oleh beberapa sebab diantaranya, tujuan. Dalam proses ini biasanya organisasi adalah hal yang paling bisa dijadikan contoh.

Kepemimpinan adalah kemampuan untuk mempengaruhi orang lain untuk melakukan suatu usaha agar tercapai tujuan yang sudah direncanakan.. Untuk dapat melakukannya, unsur-unsur seimbang seorang pemimpin harus memiliki pengetahuan dan pengalaman. Pengetahuan dan keterampilan ini dapat diperoleh dari pengalaman 
belajar secara teori ataupun dari pengalaman di dalam praktek selama menjadi kepala. Kepemimpinan di suatu organisasi perlu mengembangkan staf dan membangun iklim motivasi yang menghasilkan tingkat kinerja yang tinggi (Mahmud, 2008).

Kepemimpinan memiliki beberapa implikasi, antara lain pertama kepemimpinan berarti melibatkan orang atau pihak lain, yaitu para bawahan. Para bawahan harus memiliki kemauan untuk menerima arahan dari pemimpin. Walaupun demikian, tanpa adanya bawahan, kepemimpinan tidak akan ada juga. Kedua: seorang pemimpin yang efektif adalah seorang yang dengan kekuasaannya mampu menggugah pengikutnya untuk mencapai kinerja yang memuaskan. Ketiga: kepemimpinan harus memiliki kejujuran terhadap diri sendiri, sikap bertanggung jawab yang tulus, pengetahuan, keberanian bertindak sesuai dengan keyakina,kepercayaan pada diri sendiri dan orang lain dan kemampuan untuk meyakinkan dalam membangun organisasi.

Seorang pimpinan pada organisasi merupakan sosok orang yang bekerja dengan bantuan orang lain. Ia tidak menjalankan semua pekerjaan sendiri saja, melainkan mengarahkan orang lain dalam tim untuk melaksanakannya. Jika tugas yang diarahkan tidak dapat dilaksanakan oleh anggotanya, seorang pimpinan harus mengetahui penyebabnya (Yanuarita et al., 2019).

Konsep kepemimpinan adalah suatu hal yang meliputi aspek-aspek kepemimpinan, konsep ini memiliki sifat praktis di karenakan mudah untuk dipahami. Adapun variabel dari konsep kepemimpinan antara lain sifat, perilaku, intergratif. Oleh karena itu untuk menjadi seorang pemimpin salah satunya harus memiliki kualitas individual, memiliki prediksi ke depan, tegas, bias menjadi panutan, disiplin dan berdekasi tinggi, bias sebagai motivator.

Terdapat banyak ragam tipe kepemimpinan,masing-masing memiliki kelebihan dan kekurangan, seperti halnya tipe kepemimpinan otokratik memiliki kelebihan pimpinannya tegas, berkarakter, berwibawa, cerdas, sehingga anak buah menurut apa yang menjadi kebijakan pimpinan. Kelemahannya, anak buah tidak berkembang dan menjadi penurut, tidak memiliki ide. Kelebihan tipe kepemimpinan paternalistic dalam memimpin layaknya seorang ayah, melindungi, mengayomi, dan selalu menjalankan apa yang menjadi ide dari pimpinan. Tipe Kepemimpinan Demokratis tipe orang yang selalu 
mengandalan diskusi disaat mau mengambil keputusan tipe ini biasanya mengandalkan rasa kebersamaan.

Kedisiplinan merupakan fungsi operasional manajemen sumber daya manusia yang terpenting karena semakin baik disiplin kerja pegawai, semakin baik kinerja yang dapat dicapai. Tanpa disiplin yang baik, sulit bagi organisasi untuk mencapai hasil yang optimal. Kedisiplinan merupakan faktor yang utama yang diperlukan sebagai alat peringatan terhadap pegawai yang tidak mau berubah sifat dan perilakunya. Sehingga seorang pegawai dikatakan memiliki disiplin yang baik jika pegawai tersebut memiliki rasa tanggung jawab terhadap tugas yang diberikan kepadanya.

Suatu tingkat kelompok pekerja hanya akan terangsang untuk meningkatkan prestasi yaitu dengan adanya stimulus pembayaran insentif. Insentif tersebut dapat berupa uang dan non uang. Selanjutnya dikatakan juga bahwa motivasi yang telah tumbuh menjadi suatu prestasi harus diberi imbalan, dan imbalan itu bentuknya bisa beraneka ragam, tergantung pilihan perusahaan. Penghargaan itu berupa tepukan tangan, hingga promosi atau uang.

Bersumber pada pendapayt Foster tersebut makin meyakinkan kita bahwa perngorbanan, prestasi kerja yang telah disumbangkan untuk perusahaan oleh para pekerja memang sudah sepantasnya untuk mendapat rupiah yang sesuai. Jadi dengan pemberian penghargaan yang sesuai akan dapat memotivasi para pekerja untuk meningkatkan disiplin kerja.

Melalui berbagai kebiajakan pimpinan dapat mempengaruhi karyawan untuk dapat meningkatkan disiplin. Kebijaksanaan tersebut tentunya tidak akan bertentangan dengan kepentingan karyawan dan tidak bertentangan dengan peraturan yang berlaku dalam instansi tersebut. Salah satu unsur penggerak dalam manajemen sumberdaya manusia adalah kepuasan karyawan. Jika karyawan merasa puas terhadap pelayanan, prestasi kerja, kinerja, reward dan sanksi yang akan diterima jika terjadi pelanggaran, maka karyawan merasa senang dan termoivasi tinggi untuk bekerja yang lebih disiplin, lebih giat, lebih maksimal, sehingga dapat dicapai kinerja yang jauh lebih tinggi lagi. 


\section{METODE PENELITIAN}

Pendekatan penelitian yang digunakan dalam penelitian ini adalah dengan pendekatan kuantitatif. Objek penelitian dikenal dengan populasi yaitu objek/subjek yang mempunyai kualitas dan karakteristik tertentu yang ditetapkan oleh peneliti untuk dipelajari dan kemudian ditarik kesimpulannya (Yudiaatmaja, 2013)Sedangkan Sampel adalah suatu bagian dari populasi yang akan diteliti dan yang dianggap dapat menggambarkan populasinya (Yudiaatmaja, 2013) Mengingat populasinya sedikit maka seluruh populasi dijadikan sampel (sampel total), yaitu berjumlah 19 orang.

Dalam pendekatan kuantitatif digunakan hipoeetsis, yaitu dugaan sementara yang harus dibuktikan kebenarannya secara ilmiah (Yudiaatmaja, 2013). Dalam hal ini hipotesis nihil (ho) adalah Tidak ada hubungan antara motivasi dan kepemimpinan terhadap disiplin kerja pegawai di Kantor SDN Ngronggo 2 Kecamatan kota Kediuri. Adapun hipotesis kerja (h1) adalah terdapat hubungan yang signifikan antara Motivasi dan Kepemimpinan Terhadap Disiplin Kerja Pada Pegawai Di Kantor SDN Ngronggo 2 Kecamatan Kota Kediri. Variabel bebas dalam penelitian ini yaitu motivasi (X1) dan kepemimpinan (X2) sedangkan variabel terikatnya adalah disiplin kerja (Y). Pengumpulan data dengan menyebarkan kuisioner yang terdiri dari tiga alternative jawab, dengan jawaban ya skor 3, mungkin skor 2 dan tidak skornya 1.

Sesudah skor didapatkan kemudian ditentukan rata-rata skornya. Dari ratarata skor tersebut kemudian diklasifikasikan menurut interval tertentu sehingga dapat diberikan penilaian dan interprestasi.

$$
\text { Interval Kelas }=\frac{\text { Nilai Tertinggi-Nilai Terendah }}{3}=\frac{3-1}{3}=0,66
$$

Dengan demikian klasifikasi dari hasil rata-rata skor adalah :

$$
\begin{aligned}
& \text { 1,00 - 1,66 adalah kurang / rendah } \\
& \text { 1,67 - 2,33 adalah sedang } \\
& \text { 2,34 - 3,00 adalah baik / tinggi }
\end{aligned}
$$

Pengumpulan data dengan observasi yaitu peneliti dating ke lokasi penelitian untuk melakukan pengamatan langsung ke daerah penelitian. Pengisian questioner (Basuki \& Prawoto, 2016), dan juga dengan dokumentasi sebagai data pelengkap. 
Analisis statistik yang digunakan tehnik Koefisien Korelasi Product Moment, dengan rumus-rumus sebagai berikut :

$$
\begin{aligned}
& \text { Rxy }= \frac{\epsilon x y}{\sqrt{\left(\epsilon X^{2}\right)+\left(\epsilon Y^{2}\right)}} \\
& \text { Keterangan : } \\
& \text { Rxy } \quad=\text { Koefisien Korelasi }=\text { Product Variabel Bebas } \\
& \mathrm{X} \quad=\text { Product Variabel Tergantung } \\
& \mathrm{Y} \quad \text { = Jumlah perkalian x dengan y }
\end{aligned}
$$

Jika menggunakan rumus tersebut maka kita dapatkan nilai r (koefisien korelasi). Kegunaan tersebut adalah apakah korelasi kedua variabel itu positif atau negative maka penyusun menggunakan ketentuan sebagai berikut : Korelasi dikatakan positif, jika Nilai dalam tes korelasi > nilai kritik dalam table. Korelasi dikatakan negatif, jika Nilai dalam tes korelasi < nilai kritik dalam table. Selanjutnya, menurut (Basuki \& Prawoto, 2016)untuk menguji hipotesa yang telah ditetapkan dapat dipertahankan atau tidak, digunakan test signifikan korelasi berdasarkan harga kritik dalam table product moment sebagai berikut :

Tabel 1. Korelasi Product Moment Harga Kritik dari r Product Moment

\begin{tabular}{|c|c|c|c|c|c|}
\hline \multicolumn{3}{|c|}{ Interval Kepercayaan } & \multicolumn{3}{|c|}{ Interval Kepercayaan } \\
\hline $\mathrm{N}$. & $95 \%$ & $99 \%$ & $\mathrm{~N}$. & $95 \%$ & $99 \%$ \\
\hline$\cdots$ & $\ldots$ & $\cdots$ & 19. & 0,456 & 0,575 \\
\hline 10 & 0,632 & 0,767 & 20 & 0,444 & 0,561 \\
\hline 11 & 0,602 & 0,735 & 21 & 0,433 & 0,549 \\
\hline 12 & 0,576 & 0,708 & 22 & 0,423 & 0,537 \\
\hline 13 & 0,533 & 0,684 & 23 & 0,413 & 0,526 \\
\hline 14 & 0,532 & 0,661 & 24 & 0,404 & 0,515 \\
\hline 15 & 0,514 & 0,641 & 25 & 0,396 & 0,606 \\
\hline 16 & 0,497 & 0,623 & 26 & 0,388 & 0,496 \\
\hline 17 & 0,482 & 0,606 & 27 & 0,381 & 0,487 \\
\hline 18 & 0,468 & 0,59 & 28 & 0,374 & 0,476 \\
\hline
\end{tabular}

Sumber : (Basuki \& Prawoto, 2016) 


\section{Tabel 2. Ukuran Koefisien Korelasi Product Moment}

\begin{tabular}{|l|l|}
\hline Korelasi & Tingkat Korelasi \\
\hline $0,00-0,20$ & Korelasi Rendah Sekali \\
\hline $0,20-0,40$ & Korelasi Rendah Tapi Ada \\
\hline $0,40-0,70$ & Korelasi Sedang \\
\hline $0,70-0,90$ & Korelasi Tinggi \\
\hline $0,90-1,00$ & Korelasi Tinggi Sekali \\
\hline
\end{tabular}

Sumber : (Basuki \& Prawoto, 2016)

\section{HASIL DAN PEMBAHASAN}

Melalui teknik pengumpulan data yang telah dilakukan sesuai dengan jenis teknik pengumpulan data, yaitu observasi, kuisioner, interview dan dikumentasi. Pengumpulan data tersebut sesuai dengan jenis variabelnya, yaitu variabel motivasi, Kepemimpinan dan Disiplin kerja guru. Setiap variabel dikumpulkan datanya dengan mengisi kuesioner yang telah dibagikan, dan setelah data terkumpul sesuai dengan variabelnya dilakukan analisis statistic, pertama Analisis dan Interpretasi Data dari variabel bebas pertama (Motivasi Kerja) sebagai berikut.

Tabel 3. Interpretasi Data dari variabel bebas pertama (Motivasi Kerja)

\begin{tabular}{|l|c|c|c|c|c|c|c|c|c|c|c|l|}
\hline \multirow{3}{*}{ No } & \multirow{2}{*}{ Nama } & \multicolumn{10}{|c|}{ Score Data } \\
\cline { 3 - 16 } & Responden & $\begin{array}{c}\text { X.1. } \\
\text { A }\end{array}$ & $\begin{array}{c}\text { X.1. } \\
\text { B }\end{array}$ & $\begin{array}{c}\text { X.1. } \\
\text { C }\end{array}$ & $\begin{array}{c}\text { X.1. } \\
\text { D }\end{array}$ & $\begin{array}{c}\text { X.1. } \\
\text { E }\end{array}$ & $\begin{array}{c}\text { X.1. } \\
\text { F }\end{array}$ & $\begin{array}{c}\text { X.1. } \\
\text { G }\end{array}$ & $\begin{array}{c}\text { X.1. } \\
\text { H }\end{array}$ & $\begin{array}{c}\text { X.1. } \\
\text { I }\end{array}$ & $\begin{array}{c}\text { Total } \\
\text { Score }\end{array}$ & $\begin{array}{l}\text { Mean } \\
\text { Score }\end{array}$ \\
\hline 1 & DTM & 3 & 3 & 3 & 3 & 3 & 3 & 3 & 3 & 3 & 27 & 3 \\
\hline 2 & LTH & 3 & 3 & 3 & 3 & 3 & 3 & 3 & 3 & 3 & 27 & 3 \\
\hline 3 & LST & 3 & 3 & 3 & 3 & 3 & 3 & 3 & 3 & 3 & 27 & 3 \\
\hline 4 & WJ & 3 & 3 & 3 & 3 & 3 & 3 & 3 & 3 & 3 & 27 & 3 \\
\hline 5 & YU & 3 & 3 & 3 & 3 & 3 & 3 & 3 & 3 & 3 & 27 & 3 \\
\hline 6 & WW & 3 & 3 & 3 & 3 & 3 & 3 & 3 & 3 & 3 & 27 & 3 \\
\hline 7 & KAS & 3 & 3 & 3 & 3 & 3 & 3 & 3 & 3 & 3 & 27 & 3 \\
\hline 8 & HEN & 3 & 3 & 3 & 3 & 3 & 3 & 3 & 3 & 3 & 27 & 3 \\
\hline 9 & TRI & 3 & 3 & 3 & 3 & 3 & 3 & 3 & 3 & 3 & 27 & 3 \\
\hline 10 & MAH & 2 & 2 & 2 & 3 & 3 & 2 & 3 & 2 & 3 & 22 & 2,4 \\
\hline 11 & UTO & 3 & 3 & 3 & 3 & 3 & 3 & 3 & 3 & 3 & 27 & 3 \\
\hline 12 & YUS & 3 & 3 & 3 & 3 & 3 & 3 & 3 & 3 & 3 & 27 & 3 \\
\hline 13 & SYA & 3 & 3 & 3 & 3 & 3 & 3 & 3 & 3 & 3 & 27 & 3 \\
\hline 14 & AUD & 3 & 3 & 3 & 3 & 3 & 3 & 3 & 3 & 3 & 27 & 3 \\
\hline
\end{tabular}




\begin{tabular}{|l|l|l|l|l|l|l|l|l|l|l|l|l|}
\hline 15 & DID & 3 & 3 & 3 & 3 & 3 & 3 & 3 & 3 & 3 & 27 & 3 \\
\hline 16 & BAG & 3 & 3 & 3 & 3 & 3 & 3 & 3 & 3 & 3 & 27 & 3 \\
\hline 17 & DEW & 2 & 3 & 3 & 3 & 3 & 2 & 3 & 2 & 3 & 24 & 2,7 \\
\hline 18 & KIK & 3 & 3 & 3 & 3 & 3 & 3 & 3 & 2 & 3 & 26 & 2,9 \\
\hline 19 & KHO & 3 & 3 & 3 & 3 & 3 & 2 & 3 & 3 & 3 & 26 & 2,9 \\
\hline & \multirow{8}{*}{ N $=19$} & \multicolumn{10}{|c|}{ Total Score } \\
\cline { 2 - 11 } & & \multicolumn{10}{|c|}{ Score } & 55,9 \\
\hline
\end{tabular}

Sumber Data : Hasil Analisis Data, 2018

Tabel 4. Interpretasi Data dari variabel bebas Kedua (Kepemimpinan)

\begin{tabular}{|c|c|c|c|c|c|c|c|c|c|c|c|c|c|c|}
\hline \multirow[b]{2}{*}{ No } & \multirow[b]{2}{*}{$\begin{array}{c}\text { Nama } \\
\text { Responden }\end{array}$} & \multicolumn{13}{|c|}{ Score Data } \\
\hline & & $\begin{array}{c}\text { X.2. } \\
\text { A }\end{array}$ & $\begin{array}{c}\text { X.2. } \\
\text { B }\end{array}$ & $\begin{array}{c}\text { X.2. } \\
\text { C }\end{array}$ & $\begin{array}{c}\text { X.2. } \\
\text { D }\end{array}$ & $\begin{array}{c}\text { X.2. } \\
\text { E }\end{array}$ & $\begin{array}{c}\text { X.2. } \\
\text { F }\end{array}$ & $\begin{array}{c}X .2 . \\
G\end{array}$ & $\begin{array}{c}\text { X.2. } \\
\mathrm{H}\end{array}$ & $\begin{array}{c}\text { X.2. } \\
\text { I }\end{array}$ & $\begin{array}{c}\text { X.2. } \\
\text { J }\end{array}$ & $\begin{array}{c}\text { X.2. } \\
\text { K }\end{array}$ & $\begin{array}{l}\text { Total } \\
\text { Score }\end{array}$ & $\begin{array}{l}\text { Mean } \\
\text { Score }\end{array}$ \\
\hline 1 & DTM & 3 & 3 & 3 & 3 & 3 & 3 & 3 & 3 & 3 & 3 & 3 & 33 & 3 \\
\hline 2 & LTH & 3 & 3 & 3 & 3 & 3 & 3 & 3 & 3 & 3 & 3 & 3 & 33 & 3 \\
\hline 3 & LST & 3 & 3 & 3 & 3 & 3 & 3 & 3 & 3 & 3 & 3 & 3 & 33 & 3 \\
\hline 4 & WJ & 3 & 3 & 3 & 3 & 3 & 3 & 3 & 3 & 3 & 3 & 3 & 33 & 3 \\
\hline 5 & YU & 3 & 3 & 3 & 3 & 3 & 3 & 3 & 3 & 3 & 3 & 3 & 33 & 3 \\
\hline 6 & WW & 3 & 3 & 3 & 2 & 3 & 2 & 3 & 3 & 3 & 3 & 3 & 31 & 2,8 \\
\hline 7 & KAS & 3 & 3 & 3 & 3 & 3 & 3 & 3 & 3 & 3 & 3 & 3 & 33 & 3 \\
\hline 8 & HEN & 2 & 3 & 3 & 3 & 3 & 3 & 3 & 3 & 3 & 3 & 3 & 32 & 2,9 \\
\hline 9 & TRI & 3 & 3 & 3 & 3 & 3 & 3 & 3 & 3 & 3 & 3 & 3 & 33 & 3 \\
\hline 10 & MAH & 2 & 3 & 3 & 3 & 3 & 3 & 3 & 3 & 3 & 3 & 3 & 32 & 2,9 \\
\hline 11 & UTO & 2 & 3 & 3 & 3 & 3 & 3 & 3 & 3 & 3 & 3 & 3 & 32 & 2,9 \\
\hline 12 & YUS & 3 & 3 & 3 & 3 & 3 & 3 & 3 & 3 & 3 & 3 & 3 & 33 & 3 \\
\hline 13 & SYA & 3 & 3 & 2 & 2 & 3 & 2 & 3 & 3 & 3 & 3 & 3 & 30 & 2,7 \\
\hline 14 & AUD & 3 & 3 & 3 & 3 & 3 & 3 & 3 & 3 & 3 & 3 & 3 & 33 & 3 \\
\hline 15 & DID & 3 & 3 & 3 & 3 & 3 & 3 & 3 & 3 & 3 & 3 & 3 & 33 & 3 \\
\hline 16 & BAG & 3 & 3 & 3 & 3 & 3 & 3 & 3 & 3 & 3 & 3 & 3 & 33 & 3 \\
\hline 17 & DEW & 3 & 3 & 3 & 2 & 3 & 3 & 3 & 3 & 3 & 3 & 3 & 32 & 2,9 \\
\hline 18 & KIK & 3 & 3 & 3 & 3 & 3 & 3 & 3 & 3 & 3 & 3 & 3 & 33 & 3 \\
\hline \multirow[t]{3}{*}{19} & KHO & 2 & 3 & 3 & 3 & 3 & 3 & 3 & 3 & 3 & 3 & 3 & 33 & 2,9 \\
\hline & \multirow{2}{*}{$\mathrm{N}=19$} & \multicolumn{12}{|c|}{ Total Score } & 56,1 \\
\hline & & \multicolumn{12}{|c|}{ Mean Score } & 5,6 \\
\hline
\end{tabular}

Sumber Data : Hasil Analisis, 2018

Tabel 5. Rekapitulasi Score Data (Mean Score) Variabel X.1 dan Variabel X.2

\begin{tabular}{|c|c|c|c|c|c|}
\hline \multirow{2}{*}{ No } & \multirow{2}{*}{$\begin{array}{c}\text { Nama } \\
\text { Responden }\end{array}$} & \multicolumn{2}{|c|}{ Score Data } & Total & Mean \\
\cline { 3 - 4 } & X.1 & X.2 & Score & Score \\
\hline 1 & DTM & 3 & 3 & 6 & 3 \\
\hline 2 & LTH & 3 & 3 & 6 & 3 \\
\hline 3 & LST & 3 & 3 & 6 & 3 \\
\hline 4 & WJ & 3 & 3 & 6 & 3 \\
\hline
\end{tabular}




\begin{tabular}{|c|c|c|c|c|c|}
\hline 5 & YU & 3 & 3 & 6 & 3 \\
\hline 6 & WW & 2,8 & 3 & 5,8 & 2,9 \\
\hline 7 & KAS & 3 & 3 & 6 & 3 \\
\hline 8 & HEN & 2,9 & 3 & 5,9 & 2,9 \\
\hline 9 & TRI & 3 & 3 & 6 & 3 \\
\hline 10 & MAH & 2,9 & 2,4 & 5,3 & 2,6 \\
\hline 11 & UTO & 2,9 & 3 & 5,9 & 2,9 \\
\hline 12 & YUS & 3 & 3 & 6 & 3 \\
\hline 13 & SYA & 2,7 & 3 & 5,7 & 2,8 \\
\hline 14 & AUD & 3 & 3 & 6 & 3 \\
\hline 15 & DID & 3 & 3 & 6 & 3 \\
\hline 16 & BAG & 3 & 3 & 6 & 3 \\
\hline 17 & DEW & 2,9 & 2,7 & 5,6 & 2,9 \\
\hline 18 & KIK & 3 & 2,9 & 5,9 & 3 \\
\hline 19 & KHO & 2,9 & 2,9 & 5,8 & 2,9 \\
\hline & \multirow{2}{*yyyyy}{ N $=19$} & \multicolumn{3}{|c|}{ Total Score } & 56,1 \\
\cline { 2 - 6 } & & \multicolumn{3}{|c|}{ Mean Score } & 2,94 \\
\hline
\end{tabular}

Sumber Data : Hasil Analisis Data, 2018

Tabel 6. Rekapitulasi Score Data Tentang Displin Kerja (Y)

\begin{tabular}{|c|c|c|c|c|c|c|c|c|c|c|}
\hline \multirow[b]{2}{*}{ No } & \multirow[b]{2}{*}{$\begin{array}{c}\text { Nama } \\
\text { Responden }\end{array}$} & \multicolumn{7}{|c|}{ Score Data } & \multirow[b]{2}{*}{$\begin{array}{l}\text { Total } \\
\text { Score }\end{array}$} & \multirow[b]{2}{*}{$\begin{array}{l}\text { Mean } \\
\text { Score }\end{array}$} \\
\hline & & $\begin{array}{c}\text { Y.1. } \\
\text { A }\end{array}$ & $\begin{array}{c}\text { Y.1. } \\
\text { B }\end{array}$ & $\begin{array}{c}\text { Y.1. } \\
\text { C }\end{array}$ & $\begin{array}{l}\text { Y.1. } \\
\text { D }\end{array}$ & $\begin{array}{c}\text { Y.1. } \\
\text { E }\end{array}$ & $\begin{array}{c}\text { Y.1. } \\
\text { F }\end{array}$ & $\begin{array}{c}\text { Y.1. } \\
\text { G }\end{array}$ & & \\
\hline 1 & DTM & 3 & 3 & 3 & 3 & 3 & 3 & 3 & 21 & 3 \\
\hline 2 & LTH & 3 & 3 & 3 & 3 & 3 & 3 & 3 & 21 & 3 \\
\hline 3 & LST & 3 & 3 & 3 & 3 & 3 & 3 & 3 & 21 & 3 \\
\hline 4 & WJ & 3 & 3 & 3 & 3 & 3 & 3 & 3 & 21 & 3 \\
\hline 5 & YU & 3 & 3 & 3 & 3 & 3 & 3 & 3 & 21 & 3 \\
\hline 6 & WW & 3 & 3 & 3 & 3 & 3 & 3 & 3 & 21 & 3 \\
\hline 7 & KAS & 3 & 3 & 3 & 3 & 3 & 3 & 3 & 21 & 3 \\
\hline 8 & HEN & 3 & 3 & 3 & 3 & 3 & 3 & 3 & 21 & 3 \\
\hline 9 & TRI & 3 & 3 & 3 & 3 & 3 & 3 & 3 & 21 & 3 \\
\hline 10 & MAH & 2 & 2 & 3 & 3 & 3 & 3 & 3 & 19 & 2,7 \\
\hline 11 & UTO & 2 & 3 & 3 & 3 & 3 & 3 & 3 & 20 & 2,8 \\
\hline 12 & YUS & 3 & 2 & 3 & 3 & 3 & 3 & 3 & 20 & 2,8 \\
\hline 13 & SYA & 3 & 2 & 3 & 3 & 3 & 3 & 3 & 20 & 2,8 \\
\hline 14 & AUD & 3 & 3 & 3 & 3 & 3 & 3 & 3 & 21 & 3 \\
\hline 15 & DID & 3 & 3 & 3 & 3 & 3 & 3 & 3 & 21 & 3 \\
\hline 16 & BAG & 3 & 3 & 3 & 3 & 3 & 3 & 3 & 21 & 3 \\
\hline
\end{tabular}




\begin{tabular}{|c|c|c|c|c|c|c|c|c|c|c|}
\hline 17 & DEW & 2 & 3 & 3 & 3 & 3 & 3 & 3 & 20 & 2,8 \\
\hline 18 & KIK & 3 & 3 & 3 & 3 & 3 & 3 & 3 & 21 & 3 \\
\hline 19 & KHO & 2 & 3 & 3 & 3 & 3 & 3 & 3 & 20 & 2,8 \\
\hline & \multirow{2}{*}{$\mathrm{N}=19$} & \multicolumn{9}{|c|}{$\begin{array}{l}\text { Total } \\
\text { Score }\end{array}$} \\
\hline & & \multicolumn{9}{|c|}{$\begin{array}{l}\text { Mean } \\
\text { Score }\end{array}$} \\
\hline
\end{tabular}

Sumber Data : Hasil Analisis Data. 2018

Berdasarkan analisis data pada tabel 5 di atas, dapat diketahui bahwa mean score Motivasi dan Kepemimpinan yang merupakan variabel bebas menunjukkan angka 2,94 sehingga dapat dikategorikan tinggi sekali. Maka motivasi dan Kepemimpinan yang dilakukan Kepala Sekolah kepada guru menjadi penyebab tenaga pendidik dan kependidikan menjadi lebih disiplin. Selanjutnya untuk mengetahui rekapitulasi score data disiplin kerja pegawai, berdasarkan analisis data pada 6 diatas, dapat diketahui bahwa mean score disiplin kerja pegawai yang merupakan variabel tergantung menunjukkan angka 2,93 sehingga dapat dikategorikan tinggi sekali. Dengan demikian dapat dikatakan, bahwa disiplin kerja pegawai adalah baik. Setelah seluruh data dari masing-masing variabel dianalisis dan diinterpretasikan, maka untuk langkah berikutnya akan dilakukan perhitungan hubungan atau korelasi keterkaitan antara kedua variabel. Perhitungan Korelasi antara Variabel Bebas (X1 dan X2) dengan Variabel Tergantung (Y). Selanjutnya dilakukan perhitungan Motivasi dan Kepemimpinan yang merupakan variabel bebas (X) dan disiplin kerja yang merupakan variabel tergantung (Y) dapat dilihat pada tabel berikut

Tabel 7. Perhitungan Korelasi Pengukuran Motivasi Dan Kepemimpinan Terhadap Semangat Kerja Pegawai

\begin{tabular}{|c|c|c|c|c|c|c|c|}
\hline No. & $\mathrm{X}$ & $\mathrm{x}$ & $\mathrm{x} 2$ & $\mathrm{Y}$ & $\mathrm{y}$ & $\mathrm{y} 2$ & $\mathrm{xy}$ \\
\hline 1 & 3 & 0,057895 & 0,004681 & 3 & 0,068421 & 0,003352 & 0,0039 \\
\hline 2 & 3 & 0,057895 & 0,004681 & 3 & 0,068421 & 0,003352 & 0,0039 \\
\hline 3 & 3 & 0,057895 & 0,004681 & 3 & 0,068421 & 0,003352 & 0,0039 \\
\hline 4 & 3 & 0,057895 & 0,004681 & 3 & 0,068421 & 0,003352 & 0,0039 \\
\hline 5 & 3 & 0,057895 & 0,004681 & 3 & 0,068421 & 0,003352 & 0,0039 \\
\hline 6 & 2,9 & $-0,04211$ & 0,004681 & 3 & 0,068421 & 0,001773 & $-0,002$ \\
\hline 7 & 3 & 0,057895 & 0,004681 & 3 & 0,068421 & 0,003352 & 0,0039 \\
\hline
\end{tabular}




\begin{tabular}{|c|c|c|c|c|c|c|c|}
\hline 8 & 2,9 & $-0,04211$ & 0,004681 & 3 & 0,068421 & 0,001773 & $-0,002$ \\
\hline 9 & 3 & 0,057895 & 0,004681 & 3 & 0,068421 & 0,003352 & 0,0039 \\
\hline 10 & 2,6 & $-0,34211$ & 0,053629 & 2,7 & $-0,23158$ & 0,117039 & 0,0792 \\
\hline 11 & 2,9 & $-0,04211$ & 0,017313 & 2,8 & $-0,13158$ & 0,001773 & 0,0055 \\
\hline 12 & 3 & 0,057895 & 0,017313 & 2,8 & $-0,13158$ & 0,003352 & $-0,007$ \\
\hline 13 & 2,8 & $-0,04211$ & 0,017313 & 2,8 & $-0,13158$ & 0,020195 & 0,0186 \\
\hline 14 & 3 & 0,057895 & 0,004681 & 3 & 0,068421 & 0,003352 & 0,0039 \\
\hline 15 & 3 & 0,057895 & 0,004681 & 3 & 0,068421 & 0,003352 & 0,0039 \\
\hline 16 & 3 & 0,0578 & 0,0046 & 3 & 0,1 & 0,0033 & 0,0039 \\
\hline 17 & 2,9 & $-0,042$ & 0,0173 & 2,8 & $-0,1$ & 0,0017 & 0,0055 \\
\hline 18 & 3 & 0,057895 & 0,004681 & 3 & 0,068421 & 0,003352 & 0,0039 \\
\hline 19 & 2,9 & $-0,042$ & 0,017 & 2,8 & $-0,1$ & 0,0017 & 0,0055 \\
\hline $\mathrm{N}$ & 56,1 & \multirow{2}{*}{0} & 0,20 & 56 & 0 & 0,186 & \multirow{2}{*}{0,1462} \\
\hline $\mathrm{S}$ & 2,94 & & - & - & - & - & \\
\hline
\end{tabular}

Sumber Data : Hasil Analisis Data. 2018

Keterangan : $\mathrm{X}=$ Motivasi dan Kepemimpinan

$$
\mathrm{Y}=\text { Disiplin Kerja }
$$

Selanjutnya hasil perhitungan tersebut dimasukkan ke dalam rumus Product Moment menurut Pearson sebagai berikut : “Perhitungan Korelasi Product Moment Antara Motivasi Dengan Disiplin Kerja Pegawai (Y) adalah

$$
\begin{aligned}
& r_{x y}=\frac{\sum x y}{\sqrt{\left(\sum x^{2}\right)\left(\sum y^{2}\right)}} \\
& r_{x y}=\frac{0,1462}{\sqrt{(0,20)(0,18)}} \\
& r_{x y}=\frac{0,1462}{\sqrt{0,036}} \\
& r_{x y}=\frac{0,1462}{0,1897} \\
& r_{x y}=0,7706
\end{aligned}
$$

Berdasarkan hasil perhitungan korelasi tersebut di atas di peroleh $r_{x y}=0,7706$ maka dapat diketahui bahwa Variabel Bebas ( X ) yaitu Motivasi dan Kepemimpinan 
terhadap Variabel Tergantung ( Y ) yaitu Disiplin Kerja, mempunyai korelasi tinggi. Tingkat korelasinya dikatakan tinggi sebab $r_{x y}=0,7706$ bila dikonsultasikan dengan daftar koefisien korelasi product moment lebih besar dari pada harga kritik dari pearson untuk $\mathrm{N}=19$ dengan taraf kepercayaan 95\% menunjukkan angka 0,456 Tingkat korelasinya dikatakan tinggi karena menurut ukuran koefisien korelasi Product Moment berada antara 0,700-0,900 sehingga dapat disimpulkan bahwa antara kedua variabel tersebut signifikan atau terbukti.

\section{KESIMPULAN DAN SARAN}

1. Hipotesa Nihil $\left(H_{0}\right)$ yang menyatakan Tidak Ada Hubungan antara Motivasi dan Kepemimpinan terhadap Displin Kerja Pegawai di SDN Ngronggo 2 Kecamatan Kota Kediri, di tolak

2. Hipotesa Kerja $\left(H_{1}\right)$ yang menyatakan Ada Hubungan antara Motivasi dan Kepemimpinan terhadap Disiplin Kerja Pegawai di Kantor SDN Ngronggo 2 Kecamatan Kota Kediri, di terima.

\section{REFERENSI}

Basuki, A. T., \& Prawoto, N. 2016. Analisis Regresi dalam Penelitian Ekonomi dan Bisnis. Depok: Raja Grafindo Persada.

Brahmasari, I. A., \& Suprayetno, A. 2008. Pengaruh motivasi kerja, kepemimpinan dan budaya organisasi terhadap kepuasan kerja karyawan serta dampaknya pada kinerja perusahaan (Studi kasus pada PT. Pei Hai International Wiratama Indonesia). Jurnal Manajemen Dan Kewirausahaan, 10(2), 124-135.

Firmansyah, H. 2009. Hubungan motivasi berprestasi siswa dengan hasil belajar pendidikan jasmani. Jurnal Pendidikan Jasmani Indonesia, 6(1), 41-42.

Mahmud, A. 2008. Pengaruh Motivasi Terhadap Minat Mahasiswa Untuk Mengikuti Pendidikan Profesi. Dinamika Pendidikan, 3(1).

Potu, A. 2013. Kepemimpinan, motivasi, dan lingkungan kerja pengaruhnya terhadap kinerja karyawan pada Kanwil Ditjen Kekayaan Negara Suluttenggo dan Maluku Utara di Manado. Jurnal EMBA: Jurnal Riset Ekonomi, Manajemen, Bisnis Dan Akuntansi, 1(4). 
REZA, R. A., \& Dirgantara, I. 2010. Pengaruh gaya kepemimpinan, motivasi dan disiplin kerja terhadap kinerja karyawan PT Sinar Santosa Perkasa Banjarnegara. Universitas Diponegoro.

Sriwidodo, U., \& Haryanto, A. B. 2010. Pengaruh kompetensi, motivasi, komunikasi dan kesejahteraan Terhadap kinerja pegawai dinas pendidikan. Jurnal Manajemen Sumber Daya Manusia, 4(1), 47-57.

Yanuarita, H. A., Hariyanto, \& Hanum, F. 2019. Pengaruh Pemberdayaan Dan Pembinaan Terkemuka Terhadap Kerja Karyawan Di Satuan Sabhara Polres Batu. Mediasosian, Vol. 3(2).

Yudiaatmaja, F. 2013. Analisis Regresi dengan Menggunakan Aplikasi Komputer Statistik. Gramedia Pustaka Utama. 